\title{
炭化チタンウイスカー/アルミナ系複合セラミックスの緻密化, 機械的性質及び切削性能に対する放電プラズマ焼結の効果
}

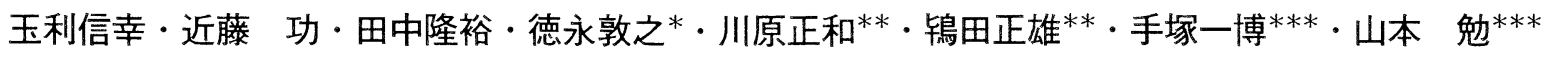 \\ 大阪工業技術研究所, 563 池田市緑丘 1-8-31 \\ *セントラル硝子 (株) 化学研究所, 755 宇部市大字沖宇部 5253 \\ **住友石炭鉱業(株)技術本部研究開発部，213 川崎市高津区坂戸 3-2-1，かながわサイエンスパーク東棟 208 \\ ***ダイジェット工業(株), 547 大阪市平野区加美東 2-1-8
}

\section{Effect of Spark Plasma Sintering on Densification, Mechanical Properties and Cutting Performance of Titanium Carbide Whisker/Alumina Composite Ceramics}

\author{
Nobuyuki TAMARI, Isao KONDOH, Takahiro TANAKA, Nobuyuki TOKUNAGA*, \\ Masakazu KAWAHARA**, Masao TOKITA**, Kazuhiro TEZUKA*** and Tsutomu YAMAMOTO*** \\ Osaka National Research Institute, AIST, 1-8-31, Midorigaoka, Ikeda-shi 563 \\ *Chemical Research Center, Central Glass Co., Ltd., 5253, Oaza Okiube, Ube-shi 755 \\ ** Research \& Develpoment Department, Technical Development Division, Sumitomo Coal Mining Co., Ltd., East 208, KSP, \\ 3-2-1, Sakato, Takatsu-ku, Kawasaki-shi 213 \\ ***Dijet Industrial Co., Ltd., 2-1-8, Kamihigashi, Hirano-ku, Osaka-shi 547
}

\begin{abstract}
Composite ceramics of alumina mixed with 20 vol\% titanium carbide whiskers were fabricated by spark plasma sintering (SPS) and hot-pressing at 1300 to $1650^{\circ} \mathrm{C}$ under $30 \mathrm{MPa}$ for $5 \mathrm{~min}$. The SPS brought about dense titanium carbide whisker/alumina composites at a sintering temperature of $1500^{\circ} \mathrm{C}$, which was about $100^{\circ} \mathrm{C}$ lower than that in the hot-pressing process. The composites obtained by SPS had mechanical properties slightly higher than those obtained by hot-pressing. The alumina matrix grains in the composites prepared by SPS grew larger than those by hot-pressing. The cutting performance (wear resistance and fracture resistance) of dense sintered bodies fabricated by SPS resulted to be slightly improved over those by hot-pressing, due to their higher mechanical properties. [Received April 23, 1997; Accepted July 4, 1997]
\end{abstract}

Key-words : Spark plasma sintering, Composite ceramics, Alumina, Titanium carbide whiskers, Densification, Mechanical properties, Cutting performance

\section{1. 緒言}

放電プラズマ焼結法（SPS ; spark plasma sintering）は， ホットプレスなどと同様に粉体を加圧しながら, 昇温する加圧 焼結法の一種である。この手法は, 原料粉体に圧力をかけなが ら on-off 直流パルス電圧を印可し，その際粒子間で生じるミ クロ放電現象を利用することにより, ホットプレス焼結や雾团 気炉などの通常の熱的作用による焼結法に比べて低温・短時間 での焼結が可能な新規な焼結方法である1).

著者らは, 助剤に 5 mass\%のアルミナと 2 mass\%のイット リアを添加した炭化ケイ素セラミックス及びアルミナウイス カーハジルコニア系複合セラミックスの緻密化と機械的性質に 対する放電プラズマ焼結の効果をホットプレス焼結の場合と比 較検討してきた。そして，ホットプレス焼結に比べて放電プラ ズマ焼結を用いることにより，緻密化温度を低下させることが でき，また，同程度の緻密体でも放電プラズマ焼結体の方が高 い機械的性質を示すことを報告してきた2,3).

また，著者らはこれまでホットプレスを用いて炭化チタンウ イスカー/アルミナ系複合セラミックスの緻密化, 機械的性質, 耐酸化性及び切削性能について調べてきた．その結果，機械的 性質の向上に対して0.5 mass\%のイットリア添加が有効である ことや，この複合セラミックスは炭化チタン粒子分散アルミナ 系複合セラミックスや炭化ケイ素ウイスカー/アルミナ系複合 セラミックスなどの市販のセラミック複合体切削工具と同程度 の切削性能を持つことなどを報告してきた ${ }^{4) \sim 77}$.

ここでは, 放電プラズマ焼結法を炭化チタンウイスカー/ア ルミナ系複合セラミックスの作製に利用し, 緻密化, 機械的性
質や切削性能に対する放電プラズマ焼結法の効果を同じ条件で 焼結したホットプレス体と比較したので報告する。

\section{1 原料及びその調製}

\section{2. 実験方法}

アルミナ粉末としては， $\alpha$ 型の大明化学工業製のタイミクロ ン TM-D (平均粒径 : $0.22 \mu \mathrm{m}$ ) を使用した。一方, 炭化于タ ン $(\mathrm{TiC})$ ウイスカーは, CVD 法により製造された $\mathrm{Ti} / \mathrm{C}$ 組成 比が 1 のものを用いた。 そのウイスカーは, 平均径 $1.3 \mu \mathrm{m}$ で,

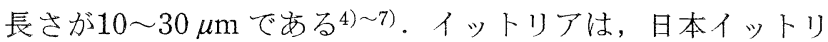
ウム製の平均粒径 $0.4 \mu \mathrm{m}$ を用いた.

アルミナに対してイットリアを 0.5 mass\%添加した。これら の粉末に TiC ウイスカーを $20 \mathrm{vol} \%$ 加え，アルミナボールと一 緒にポリエチレン製ポットに入れ，エタノール中，24hの湿式 ボールミルにより混合・分散し，ロータリーエバポレーターに より乾燥した後, 16 メシュのふるいを通したものを焼結に 供した。

\section{2 焼結}

原料混合粉末を窒化ホウ素を塗布した黒鉛型枠に入れ，放電 プラズマ焼結装置（住友石炭鉱業製，SPS-2080）とホットプ レス装置を用いて焼結を行った。手順としては，あらかじめ $30 \mathrm{MPa}$ の圧力を負荷しながら，放電プラズマ焼結では約 $200^{\circ} \mathrm{C} / \mathrm{min}$ で, ホットプレス焼結では約 $70^{\circ} \mathrm{C} / \mathrm{min}$ で所定温度 まで上げ， $5 \mathrm{~min}$ 保持した，終了後は，直ちに圧力を解放する とともに自然放冷した。焼結温度は $1300 \sim 1650^{\circ} \mathrm{C}$ である。そ の温度は黒鉛型恷の温度を光高温計で測定した。得られた焼結 
体は，放電プラズマ焼結では径 $40 \mathrm{~mm}$, 厚さ $5 \mathrm{~mm}$ ，ホットプ レス焼結では $20 \times 40 \times 5 \mathrm{~mm}$ の大きさであった。

\section{3 機械的性質}

得られた焼結体は，JIS 規格に従って密度と室温曲げ強度， ビッカース硬度及び破壊勒性值（IF 法）の機械的性質を調べ た.これらの詳細については, 既報を参照のこと4) 7).

\section{4 切削性能}

切削試験では耐摩耗性と耐欠損性を調べた8)。耐摩耗試験に 抢いては，ワーク（被削材）として鋳鉄（FC250）の丸棒を用 いた. 周速 $200 \mathrm{~m} / \mathrm{min}$, 送り $0.2 \mathrm{~mm} / \mathrm{rev}$, 切込及 $2 \mathrm{~mm}$ で, 乾式外径旋削により試験を行った。この試験により，先端及び 逃げ面の摩耗幅を測定し，評価した。また，耐欠損性試験にお いてもワークは鋳鉄（FC250）を用いた。これに対称的に 8 個の溝を付けて断続旋削試験を行った。周速は $300 \mathrm{~m} / \mathrm{min}$ ，切 込みは $2 \mathrm{~mm}$ とした。送りは $0.1 \mathrm{~mm} / \mathrm{rev}$ から始め,インサー

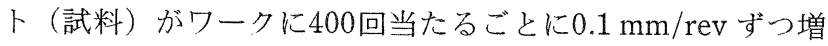
やし，インサートが久損するまでの衝撃回数で耐欠損性を評価 した。なお，耐欠損性試験は各4回行った。インサートとして は， $1600^{\circ} \mathrm{C} て ゙$ 作製した両焼結体を使用した。その形状は， ISO 規格のSNGN120408とした。すなわち,チップ形状が四 角, 切れ刃長さが $12.7 \mathrm{~mm}$, 厚さが $4.76 \mathrm{~mm}$, コーナー半径が $0.8 \mathrm{~mm}$ ，逃げ角が 00 のものを用いた。

\section{1 緻密化と曲げ強度}

\section{3. 結果及び考察}

図 1 に, TiC ウイスカー/アルミナ系複合セラミックスの緻 密化に対する放電プラズマ焼結及びホットプレス焼結の各焼結 温度の影響を示す。ホットプレ久焼結においては， $1400^{\circ} \mathrm{C}$ 以 下の焼結温度では相対密度 $90 \%$ 以下の焼結体しか得られな かった。市た $1500^{\circ} \mathrm{Cでも} 97 \%$ 程度で，99\%以上の緻密な焼 結体を得るには $1600^{\circ} \mathrm{C}$ 焼結温度が必要であった。一方, 放

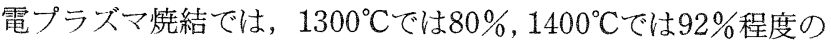
相対密度しか得られなかったが，ホットプレス焼結に比べて $100^{\circ} \mathrm{C}$ ぼ低い $1500^{\circ} \mathrm{C}$ か $599 \%$ 以上の相対密度を持つ緻密な焼 結体が得られた。このように放電プラズマ焼結は, 著者らがこ れまで行ってきたアルミナウイスカートジルコニア系複合セラ ミックスや炭化ケイ素系セラミックスの場合と同様に, 緶密化 に対してホットプレスより大きな効果を示した2),3)。これは, 放電プラズマ焼結では粒子間で生じるミクロ放電による自己発

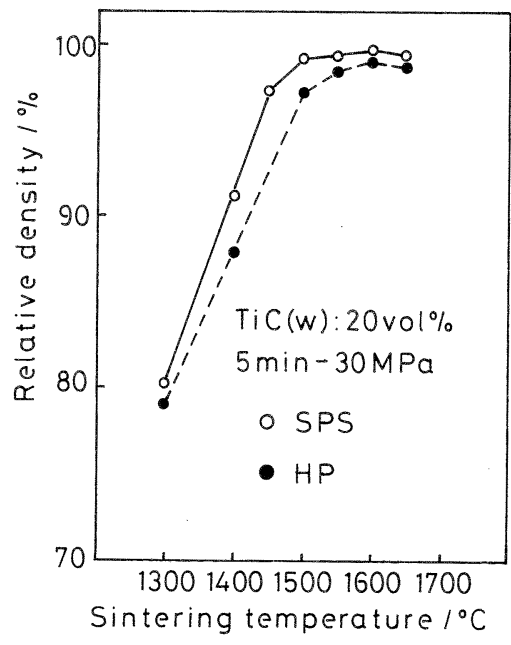

Fig. 1. Effect of sintering temperature on densification of 20 vol\% TiC whisker/alumina composites.

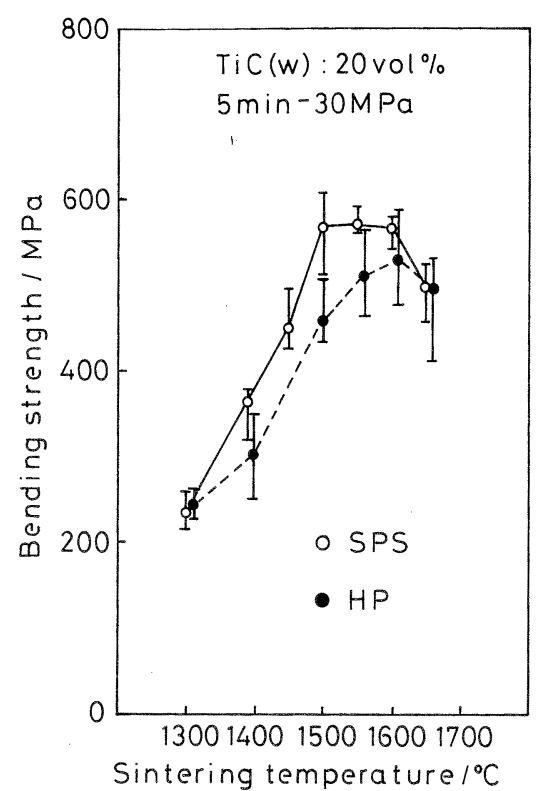

Fig. 2. Effect of sintering temperature on room temperature bending strength of $20 \mathrm{vol} \% \mathrm{TiC}$ whisker/alumina composites.

熱，放電プラズマによる粒子表面の清浄化や放電衝撃圧力によ る物質移動の高速化などのホットプレス焼結では起こり得ない

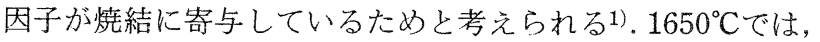
いずれの焼結法でも密度が低下する傾向にあった。これは，高 温においては TiC とアルミナの間で以下のような反応が生じ やすいことが影響していると推察される9),10).

$$
y \mathrm{Al}_{2} \mathrm{O}_{3}+\mathrm{TiC}=y \mathrm{Al}_{2} \mathrm{O} \uparrow+\mathrm{TiC}_{x} \mathrm{O}_{y}+y \mathrm{CO} \uparrow
$$

図 2 に, 図 1 の試料の室温曲げ強度の測定結果を示す。 ホットプレス焼結では, 曲げ強度は焼結温度とともに，すなわ ち緻密化の向上とともに高くなった。しかし, 緻密化した $1600^{\circ} \mathrm{C}$ で $530 \mathrm{MPa}$ 程度の強度しか得られなかった。一方, 放電プラズマ焼結においては，ホットプレス焼結と同様に焼結 温度が高くなると強度は高くなり，1500 $\mathrm{C}$ 以上では既報の $1600^{\circ} \mathrm{C}$ で30 min ホットプレ久焼結したものの強度と同程度の

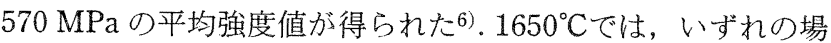
合も緻密化の低下などの影響により強度低下が生じた。

\section{2 微細組織}

焼結温度 $1500^{\circ} \mathrm{C}$ 及び $1600^{\circ} \mathrm{C} て ゙$ 得られた両焼結体の破断面の 走查型電子顕微鏡（SEM）写真を図 3 に示す。マトリックス のアルミナ粒子はホットプレス体に比べて放電プラズマ焼結体 ではかなり大きくなっていた。同様な現象がアルミナウイス カー/ジルコニア系複合セラミックスでも認められている2). セラミックスにおいては，粒成長が進んでいるほど強度は低い のが通例である。しかしながら，本ウイスカー複合セラミック スではこのように放電プラズマ焼結体内のアルミナマトリック ス粒子の方が粒成長していたが，強度は放電プラズマ焼結体が 高かった。これは, 既報で述べたように放電プラズマ焼結体の 方がホットプレス焼結体に比ベて，パルス状の数千アンペアの 直流電流の印加による自己発熱や衝撃王力などの作用によりウ イスカーとマトリックスの結合力が強いためと考えられる2).

また，ホットプレス体内のアルミナマトリック久粒子は粒界 破壊だけにより破壊している，一方，放電プラズマ焼結体内で は粒内破壊しているアルミナマトリックス粒子が多く見られ る.このような現象は, アルミナウイスカー/ジルコニア系複 合セラミックスに抢いても認められた2). 


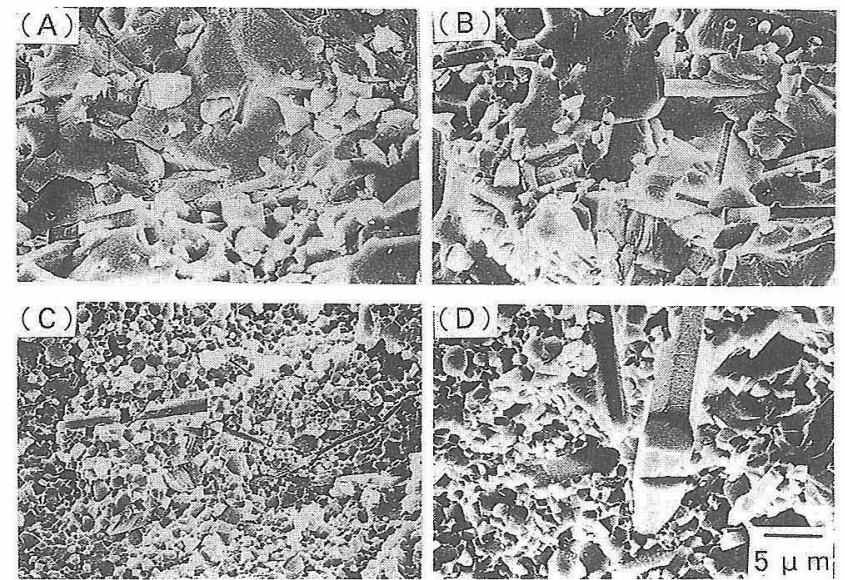

Fig. 3. Scanning electron micrographs of fractured surface of each composite.

(A), (B) : Spark plasma sintering, (C), (D) : hot-pressing. Sintering temperature; $(\mathrm{A}),(\mathrm{C}): 1500^{\circ} \mathrm{C},(\mathrm{B}),(\mathrm{D}): 1600^{\circ} \mathrm{C}$.

\section{3 硬度と破壊鞄性}

図 4 に，ビッカース硬度の測定結果を示す。いずれの場合も 焼結温度とともに, すなわち緻密化とともに硬度は高くなっ た。硬度の場合は強度ほど大きな差異は見られないが，いずれ の焼結温度でも放電プラズマ焼結体の硬度がホットプレス体の 值を若干上回っている．このこともホットプレス体に比べて放

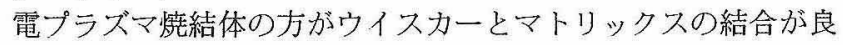
いことを示唆している.

緻密な焼結体について IF 法により測定した破壞勒性の結果 を図 5 に示す．ここで，弾性率は曲げ共振法により求めた既報 のウイスカー添加率 $20 \mathrm{vol} \%$ の值， $376 \mathrm{MPa}$ を用いた6). 破壊 勒性值も硬度の場合と同様に放電プラズマ焼結体の方がわずか ではあるが高い值を示した。これは, 恐らくアルミナウイス カーハシルコニア系複合セラミックスで述ベたように放電プラ ズマ焼結体の強度がホットプレス体より高いことが影響してい ると推察される.

前述のように，本ウイスカー複合セラミックスの放電プラズ

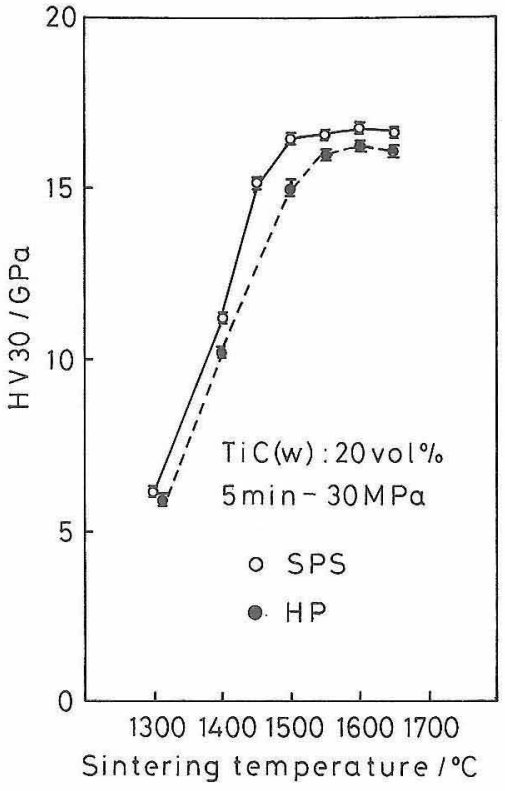

Fig. 4. Effect of sintering temperature on Vickers hardness.

マ焼結による破懐勒性や曲げ強度などの機械的特性の向上の度 合いがアルミナウイスカートシルコニア系複合セラミックスに 比べてかなり小さいのは, 両複合セラミックスのウイスカーと マトリックスの熱膨張係数差が異なり，それが結合状態に影響 していることが一因と推察される.すなわち，本ウイスカー複 合セラミックスではウイスカーとマトリックスの熱膨張係数に ほとんど差がない（ $\mathrm{TiC}: 7.9 \times 10^{-6} \mathrm{~K}^{-1}, \mathrm{Al}_{2} \mathrm{O}_{3}: 8.1 \times 10^{-6}$ $\left.\mathrm{K}^{-1}\right)$ ために，放電プラズマ焼結法とホットプレス法で作製し た試料の間でウイスカーとマトリックスの結合力が大きくは異 なっていないと考えられる。一方，アルミナウイスカーバル コニア系複合セラミックスでは熱膨張係数差が大きく $\left(\mathrm{Al}_{2} \mathrm{O}_{3}\right.$ ： $\left.8.1 \times 10^{-6} \mathrm{~K}^{-1}, \mathrm{ZrO}_{2}: 11.6 \times 10^{-6} \mathrm{~K}^{-1}\right)$ ，両焼結法で作製した 試料の間でウイスカーとマトリックスの結合力が大きく異なっ ているために機械的特性に顕著な差が生じたと考えられる.そ のほかに，本ウイスカー複合セラミックスにおいては，(1)式

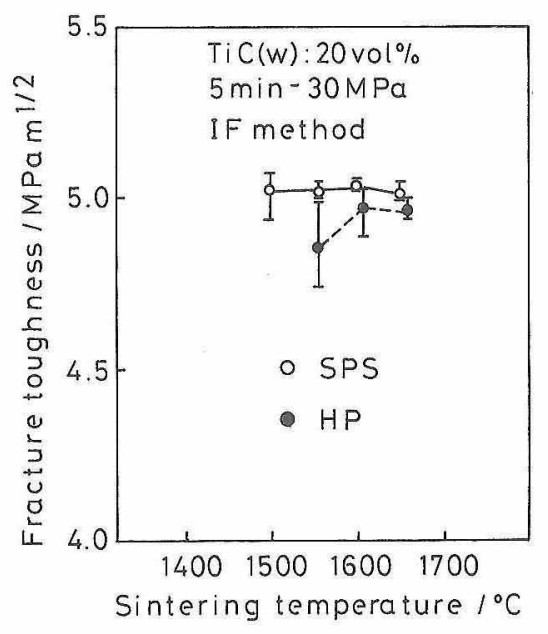

Fig. 5

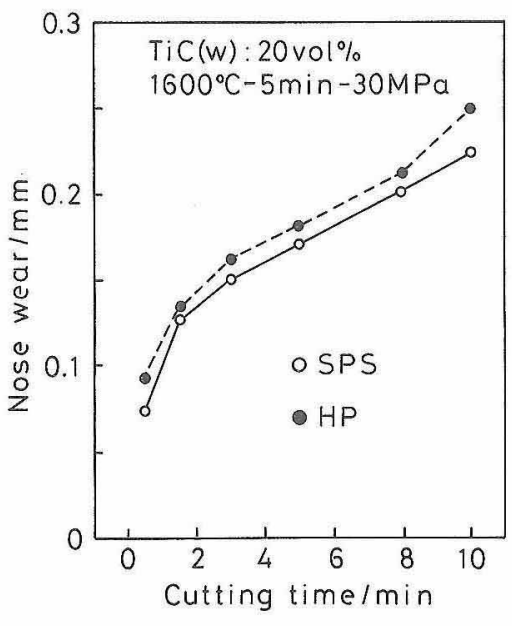

Fig. 6

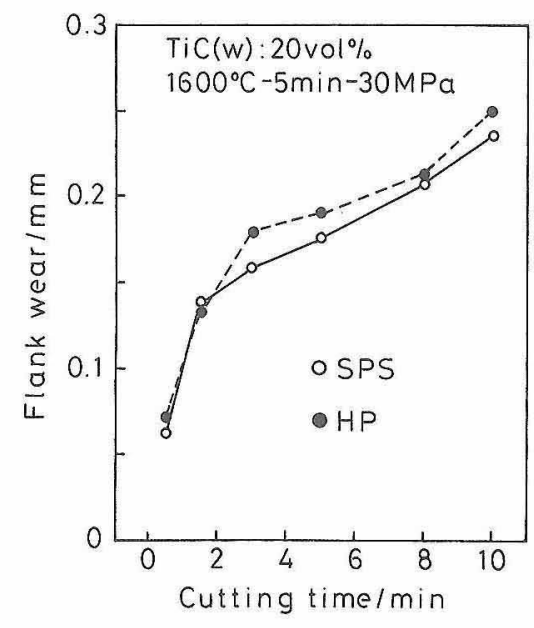

Fig. 7

Fig. 5. Effect of sintering temperature on fracture toughness.

Fig. 6. Nose wear curves of 20 vol\% $\mathrm{TiC}$ whisker/alumina composites sintered at $1600^{\circ} \mathrm{C}$ in cast iron (FC250) turning. Machining conditions ; cutting speed : $200 \mathrm{~m} / \mathrm{min}$, depth of cut : $2 \mathrm{~mm}$, feed rate $: 0.2 \mathrm{~mm} / \mathrm{rev}$.

Fig. 7. Flank wear curves of $20 \mathrm{vol} \% \mathrm{TiC}$ whisker/alumina composites sintered at $1600^{\circ} \mathrm{C}$ in cast iron (FC250) turning. Machining conditions ; cutting speed : $200 \mathrm{~m} / \mathrm{min}$, depth of cut : $2 \mathrm{~mm}$, feed rate $: 0.2 \mathrm{~mm} / \mathrm{rev}$. 
に示す反応が起こりやすいことも, 両焼結法で得られた焼結体 のウイスカーとマトリックスの結合力に大きな差異が生じな かった原因と考えられる.

\section{4 切削性能}

図 6 及び図 7 K，丸棒の鋳鉄（FC250）に対する連続旋削加 エに抢ける $1600^{\circ} \mathrm{C} て ゙$ 焼結した各複合体の先端及び逃げ面の摩 耗幅の増加状況を示す。両図より, 先端摩耗幅及び逃げ面摩耗 幅とも放電プラズマ焼結により作製した焼結体の方がほとんど の切削時間でホットプレスによるものよりわずかではあるが小 さい傾向にあることが分かる．このように放電プラズマ焼結体 の耐摩耗性がホットプレス焼結体より少しばかり良いのは, 3.1節及び3.3節で示したように曲げ強度や硬度などが放電プラ ズマ燒結体の方がホットプレス焼結体より若干高いことが影響 していると推察される。

図 8 K, 図 6 及び図 7 と同じ試料について, 断続切削試験 による耐欠損性を調べた結果を示す。この測定においてはばら つきがあるが，4回の実験に抢ける平均値及び下限值上も放電 プラズマ焼結体の方が若干耐欠損性に優れている傾向にあるこ とを示唆している．断続切削に抢ける耐欠損性は主に勒性値に 依存すると言われている11)。したがって，放電プラズマ焼結 体の耐欠損性が少し良いのは，3.3節に示した勒性の結果の反 映と考えられる.

これまでの機械的性質, 微細構造及び切削性能の結果より,

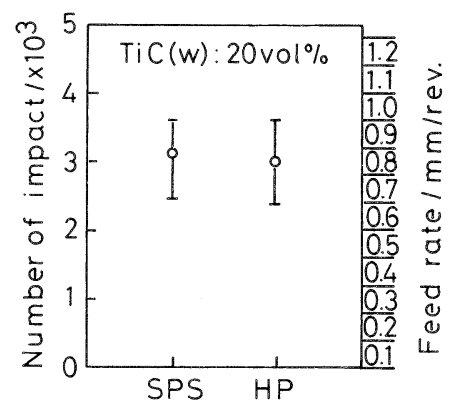

Fig. 8. Number of impact up to failure for 20 vol\% TiC whisker/alumina composites sintered at $1600^{\circ} \mathrm{C}$ in cast iron ( $\mathrm{FC} 250)$ intermittent turning.

Machining conditions ; cutting speed : $300 \mathrm{~m} / \mathrm{min}$, depth of cut : 2 $\mathrm{mm}$. $1500^{\circ} \mathrm{C}$ で放電プラズマ焼結により作製した焼結体も同程度の 切削性能を持つことが示唆される。

\section{4. まとめ}

ウイスカー添加量 $20 \mathrm{vol} \%$ の TiC ウイスカー/アルミナ系複 合セラミックスの緻密化，機械的性質及び切削性能に対する放 電プラズマ焼結の効果を調べた。その結果, 次の知見が得られ た.

（1）放電プラズマ焼結を用いることにより，ホットプレス 焼結に比べて $100^{\circ} \mathrm{C} ほ と ゙$ 低い $1500^{\circ} \mathrm{C}$ から緻密な複合セラミック スをもたらした。

(2) 放電プラズマ焼結により得られた複合セラミックスは ホットプレス焼結体よりわずかではあるが高い曲げ強度, 硬度 及び破壊勒性值を示した。

（3）放電プラズマ焼結で作製された複合セラミックス内の アルミナマトリックス粒子はホットプレス体のものより粒成長 していた

(4) 放電プラズマ焼結体の切削性能（耐摩耗性及び耐欠損 性）は，その機械的性質が若干高いためホットプレス体より少 しばかり良い傾向が認められた。

\section{文献}

1) 铇田正雄, 粉体工学会誌, 30, 790-84 (1993).

2）近藤 功, 田中隆裕, 玉利信幸，J. Ceram. Soc. Japan, 102, 505-07 (1994).

3) N. Tamari, T. Tanaka, K. Tanaka, I. Kondoh, M. Kawahara and M. Tokita, J. Ceram. Soc. Japan, 103, 740-42 (1995).

4）近藤 功, 田中隆裕, 田中孝治, 玉利信幸, J. Ceram. Soc. Japan, 103, 404-06 (1995)

5）玉利信幸, 田中隆裕, 近藤 功, J. Ceram. Soc. Japan, 103, 506-10 (1995).

6）玉利信幸, 田中隆裕, 近藤 功, 手塚一博, 山本 勉, $J$. Ceram. Soc. Japan, 104, 439-43 (1996).

7）玉利信幸, 田中隆裕, 近藤 功, 徳永敦之, 手塚一博, 山本 勉, J. Ceram. Soc. Japan, 104, 892-96 (1996).

8）山本 勉, “セラミックス系複合材料を知る事典”, 日本複合 材料学会編, アグネス承風社 (1990) pp. 120-26.

9) Y. W. Kim and J. G. Lee, J. Am. Ceram. Soc., 72, 1333-37 (1989).

10) T. Ishigaki, K. Sato and Y. Moriyoshi, J. Mater. Sci. Lett., 8, 678-80 (1989).

11）田島俊造, 山根八洲男, 黒木英憲, 鳴瀧則彦, 粉体および粉 末治金，42，464-68 (1995) 